\title{
Aplikasi Google Meet dan Power Point untuk Pembelajaran Sejarah Indonesia pada Masa Pandemi Covid-19
}

\author{
The Application of Google Meet and Power Point for Teaching the Indonesia History \\ in Covid 19 Pandemi Era
}

Stepanus Harinto

SMK Negeri 1 Bawang Banjarnegara, Jawa Tengah

\begin{tabular}{l} 
ARTICLE INFO \\
\hline Article history: \\
DOI: \\
10.30595/pssh.v1i.76 \\
Submitted: \\
April 12, 2021 \\
Accepted: \\
June 10, 2021 \\
Published: \\
June 14, 2021
\end{tabular}

Keywords:

Learning, Google Meet, Power Point, Covid-19

\begin{abstract}
The learning approach of Indonesia History using by Google Meet and Power Point in Covid 19 Pandemi era have background of the application by WhatsApp, Google Classroom, MsWord, Google Form, Google Drive hasn't been resulted in daily assessment is very bad. This application increase the meeting by using Google Meet and Power Point. The purpose of it to develop the result of the daily assessment for students in studying Indonesia History in class AKL 1 SMK Negeri 1 Bawang in the second semester of 2020-2021. By addition of this application of Google Meet and Power Point in rate of 75, after the application has been done the result is about 80 , 28. It can be included that the increasing of the application of Google Meet and Power Point is very useful significantly.
\end{abstract}

This work is licensed under a Creative Commons Attribution 4.0 International License.

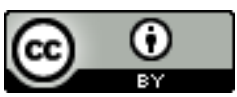

\author{
Corresponding Author: \\ Stepanus Harinto \\ SMK Negeri 1 Bawang Banjarnegara Jawa Tengah \\ Jalan Raya Pucang Nomor 132 Bawang Banjarnegara Jawa Tengah Indonesia \\ Email : stepanusharinto@gmail.com
}


seseorang tersebut mengalami keberhasilan. Diantara indikator keberhasilan adalah daya serap bahan pengajaran yang diajarkan mencapai prestasi tinggi, baik secara individual maupun secara kelompok [3].

Untuk mencapai perubahan yang baik tentunya ada metode pembelajaran. Metode pembelajaran formal umumnya dilakukan di sekolah berlangsung melalui tatap muka (face to face). Pembelajaran tatap muka adalah kegiatan pembelajaran yang berupa proses interaksi langsung antara peserta didik (siswa) dan pendidik [4]. Pembelajaran konvensional ini biasa dilakukan sebelum abab 21. Perkembangan teknologi dan informasi pada abad 21 mempengaruhi proses pembelajaran. Pembelajaran yang disebut dengan pembelajaran abad 21 tersebut diiringi dengan adanya perkembangan dan pemanfaatan teknologi informasi dan komunikasi [5]. Diantara yang baru berlangsung adalah metode Pembelajaran Jarak Jauh. Pembelajaran Jarak Jauh, dalam jaringan atau daring sudah diatur berdasarkan Peraturan Menteri Pendidikan dan Kebudayaan Nomor 22 Tahun 2016 tentang Proses Pendidikan Dasar dan Menengah [6].

Dengan semakin berkembangnya teknologi informasi dan komunikasi yang didukung dengan adanya internet, maka pembelajaran abad 21 menjadi lebih mudah dilaksanakan. Perkembangan Pembelajaran Jarak Jauh, Pembelajaran Daring terus berevolusi seiring dengan semakin kayanya sumber daya pembelajaran internet. Seperti halnya para connectivitas, praktik Pembelajaran Daring mengarah pada semakin signifikannya peranan peserta didik dalam proses pembelajaran, yang dahulu sebagai penerima informasi dan pengetahuan baru, akhirnya menjadi bagian sumber belajar yang aktif [7].

Pembelajaran Jarak Jauh menjadi sangat berati dengan adanya Covid-19. Suatu jenis penyakit baru yang mudah menyebar. WHO menamakan penyakit yang berasal dari China yang mulai ada tahun 2019 tersebut dengan sebutan Covid-19 atau Corona Virus Desease-2019. Penyakit yang disebabkan oleh virus ini mudah menyebar. Corona-19 terdeteksi awalnya pada akhir tahun 2019 di provinsi Wuhan China. Dari daerah ini kemudian menyebar ke negara lain, yaitu Thailand, Amerika Serikat, Jepang yang kemudian ke negara-negara lain. Indonesia mengumumkan ada warganya yang terpapar virus tersebut pada 2 Maret 2020. Presiden Joko Widodo yang didampingi Menteri Kesehatan dr. Terawan Agus Putranto yang memberikan keterangan tersebut.

Pada tanggal 11 Maret 2020, WHO menyatakan Virus tersebut telah menjadi pandemi yang menyerang seluruh dunia. WHO sebagai kepanjangan tangan dari PBB menyatakan hal tersebut karena banyaknya negara yang mendapati warganya terserang. Dunia dihebohkan dengan cepatnya penyebaran Covid-19. Virus ini begitu cepat menyebar dan menular antar manusia [8].

Untuk mengantisipasi menyebarnya Covid-19, Indonesia menyelenggarakan Pembelajaran Parak Jauh (PJJ). Pembelajaran pada masa pandemi Covid-19 memakai Pembelajaran Jarak Jauh atau Pembelajaran Online yang salah satunya menggunakan sarana internet sebagai ciri utama dalam revolusi 4.0. Pembelajaran Online lahir mulai generasi keempat setelah adanya internet. Pembelajaran Online adalah pembelajaran yang dilakukan melalui jaringan internet [9]. Dalam PJJ ciri utamanya adalah adanya keterpisahan fisik antara peserta didik (siswa) dan pengajar. Keterpisahan ini tentunya akan sangat mempengaruhi dalam keberhasilan kualitas pembelajaran. Namun walaupun mereka saling berpisah fisik, geografis mereka harus ada komunikasi atau interaksi. Dalam Pembelajaran Jarak Jauh harus ada interaksi interaksi siswa dengan materi pembelajaran, siswa dengan pengajar, dan siswa dengan siswa yang lain [10]. Ketiga interaksi itu saling mendukung dalam keberhasilan pembelajaran.

Pembelajaran Jarak Jauh memperlukan persiapan, diantaranya adalah: adanya modul yang berisi materi pembelajaran, adanya aplikasi atau sistem pembelajaran, adanya infrasturktur yang memberikan perantara, perangkat server jaringan untuk keperluan penyimpanan, komunikasi, adanya regulasi yang mengatur penyelenggarakan pembelajaran daring [11]. Pembelajaran Jarak Jauh yang mempergunakan sarana internet tersebut sangat membantu pekerjaan manusia pada masa pandemi Covid-19. Pembelajaran Jarak Jauh yang diselenggarakan di Indonesia dijadikan alasan untuk mengatasi menyebarnya dampak Covid-19. Pembelajaran Jarak Jauh untuk mengantisipasi Covid-19 tersebut mulai diberlakukan sejak keluarnya Surat Edaran Menteri Pendidikan dan Kebudayaan Nomor 4 tahun 2020 pada tanggal 24 Maret 2020. Dimana salah satu isi dalam surat tersebut adalah memberlakukan Pembelajaran Jarak Jauh. Pembelajaran dari tingkat pendidikan dasar sampai perguruan tinggi menggunakan Pembelajaran Jarak Jauh, dimana pembelajaran tetap berlangsung tapi pembelajar tidak datang ke sekolah atau kampus [12].

Pembelajaran didesain atau dirancang dengan maksud agar memudahkan proses belajar [13]. Dalam hal ini pembelajaran adalah untuk mempermudah dalam mencapai keberhasilan belajar pada masa pandemi Covid-19. Maka dalam hal ini guru harus mendesain bagaimana keberhasilan siswa dalam belajar dapat tercapai. Perlu didesain agar pembelajaran siswa dapat berhasil. Desain berarti suatu proses perencanaan yang sistematis sebelum mengembangkan sesuatu, atau melaksanakan perencanaan tertentu untuk memecahkan suatu masalah. Desain pembelajaran harus dilakukan dengan memperhatikan kondisi-kondisi di mana pembelajaran itu dilaksanakan. [14]. Desain pembelajaran adalah proses menentukan metode pembelajaran apa yang paling baik untuk dilaksanakan, agar timbul perubahan pengetahuan dan keterampilan pada diri siswa ke arah yang dikehendaki. Arah yang dikehendaki tersebut adalah menuju kepada kebaikan, kesuksesan atau keberhasilan.

Pendekatan dalam pembelajaran masa pandemi Covid-19 adalah dengan Pembelajaran Jarak Jauh yang mengandalkan internet. Internet merupakan ciri utama masa Revolusi 4.0. Pendekatan pembelajaran bisa dengan 
berbagai hal. Pendekatan menurut Kamus Umum Bahasa Indonesia adalah hal (perbuatan, usaha) mendekati atau mendekatkan [15]. Pendekatan pembelajaran adalah usaha untuk mendekatkan pembelajaran itu sendiri. Pendekatan pembelajaran juga bisa disampaikkan dengan media pembelajaran. Media secara umum dipahami sebagai perantara dari suatu informasi yang berasal dari sumber informasi untuk diterima oleh penerima. Media pembelajaran adalah segala bentuk dan sarana penyampaian informasi yang dibuat atau dipergunakan sesuai dengan teori pembelajaran, yang dapat digunakan untuk tujuan pembelajaran dalam menyalurkan pesan, merangsang pikiran, perasaan, perhatian, dan kemauan siswa sehingga dapat mendorong terjadinya proses belajar yang disengaja, bertujuan, dan terkendali [16]. Internet adalah sarana utama dalam Pembelajaran Jarak Jauh. Ada berbagai macam jenis dalam Pembelajaran Jarak Jauh atau online [17]. Berdasarkan skema interaksi, berdasarkan model desain, berdasar desain penggunaan. Pembelajaran Online ini memiliki beragam jenis, yang terpenting adalah penerapan prinsip-prinsip yang mendukung berkualitasnya pembelajaran. Dalam masa Revolusi 4.0 yang bercirikan internet, diantaranya WhatsApp, Google Classroom, Google Meet yang dipadu dengan aplikasi yang lain adalah contoh perkembangan teknologi informasi komunikasi dalam media pembelajaran yang dipergunakan dalam Pembelajaran Jarak Jauh.

Pelaksanakan Pembelajaran Jarak Jauh untuk mata pelajaran Sejarah Indonesia di kelas X AKL 1 di SMK Negeri 1 Bawang Banjarnegara awalnya menggunakan pendekatan dengan sarana WhatsApp, Google Classroom yang ditambah dengan pemberian materi dengan file MsWords, Google Form, dan Google Drive. WhatsApp dipergunakan untuk memberikan pemberitahuan pengumuman berkaitan dengan pembelajaran; waktu ulangan dan mengevaluasi ulangan. Google Classroom untuk memberikan materi [18] berupa file materi MsWords, Google Form untuk membuat soal-soal ulangan pilihan ganda, dan Google Drive untuk menyimpan soal-soal ulangan yang akan dikerjakan.

Penggunaan WhatsApp, Google Classroom, file materi dengan MsWord, Google Form dan Google Drive ternyata masih menghasilkan ulangan yang belum memuaskan. Hal tersebut yang menjadi latar belakang penulisan ini. Keadaan hasil ulangan yang belum memuaskan menjadi latar belakang untuk menggunakan aplikasi tambahan lain yaitu Google Meet dan Power Point. Google Meet dipergunakan karena dengan pertimbangan, pembelajaran tatap muka, walaupun hanya virtual, bisa menambah semangat untuk belajar. Selain itu belum pernah digunakan untuk mengadakan pertemuan virtual. Akhirnya pertemuan dan pembelajaran virtual digunakan, dengan menggunakan Google Meet. Google Meet dipilih karena sudah diintegrasikan di Google Classroom dan bisa untuk mengadakan pertemuan dengan para siswa walaupun hanya dengan pertemuan virtual, pertemuan tatap muka jarak jauh. Selain Google Meet aplikasi yang lain yang dipergunakan adalah Power Point. Power Point dipilih karena bisa untuk menjelaskan point-point dari materi pembelajaran Sejarah Indonesia.

Dalam hal ini aplikasi yang kemudian dipergunakan adalah WhatsApp, Google Classroom, file MsWord, Google Form, Google Drive, dan di tambah dengan Google Meet, dan Power Point (PPT)

Tujuan Google Meet, dan Power Point dipergunakan sekaligus dalam pembelajaran adalah untuk memperjelas materi pembelajaran, lebih memberikan semangat kepada para siswa untuk mengikuti pembelajaran, sehingga tujuan akhirnya yaitu para siswa mendapat hasil nilai ulangan yang meningkat dapat tercapai dibandingkan dengan ulangan yang sebelumnya.

Google Classroom merupakan layanan yang disediakan oleh Google untuk memfasilitasi guru dan murid dalam berinteraksi, untuk melakukan kegiatan belajar mengajar secara online, diantaranya pengumpulan tugas, bebagi materi pembelajaran dan berdiskusi. [19]. Google Classroom bisa digunakan sebagai sarana untuk memberikan materi pembelajaran, tugas, maupun ulangan. Materi dalam file MsWord, soal-soal ulangan dalam Google Form dikirim melalui sarana Google Classroom. Dimana materi dan soal tersebut tersimpan dalam Google Drive yang ada di Google Classroom.

Kemudian ditambah dengan Google Meet yang memang sudah diintegrasikan dalam Google Classroom sebagai sarana untuk pertemuan daring. Power Point dipergunakan karena digunakan untuk memberikan presentasi berupa penjelasan Sejarah Indonesia secara poin-poinnya saja. Pengguna Microsoft Power Point dapat merancang dan membuat presentasi yang menarik pada komputer [20]. Sarana ini sudah biasa dipergunakan dalam sarana pendidikan, pembelajaran untuk menjelaskan permasalahan berkaitan dengan pembelajaran. Microsof Power Point, salah satu program presentasi yang banyak digunakan orang untuk mempresentasikan slidenya [21]. Oleh penulis, Power Point ini dipergunakan sebagai sarana untuk meringkas dan menjelaskan pembelajaran Sejarah Indonesia.

Dengan penggunaan sarana pembelajaran WhatsApp, Google Classroom, materi dalam file MsWords, soalsoal Google Forms, Google Drive, ditambah dengan Google Meet dan Power Point dimaksudkan guru melaksanakan inovasi pembelajaran sesuai Revolusi 4.0. Inovasi pembelajaran 4.0 menekankan pada penguasaan metode pembelajaran oleh pendidik, aplikasinya di dalam kelas serta pengembangannya dalam pembelajaran. Inovasi pembelajaran memanfaatkan seluruh potensi yang ada, termasuk penguasaan teknologi serta penerapannya dalam pembelajaran. Melalui inovasi pembelajaran, pendidik diharapkan mampu menyesuaikan diri dengan perkembangan teknologi informasi dan komunikasi. Inovasi pembelajaran tersebut dilakukan dengan berbagai sumber, metode dan cara: yaitu: multimetode, internet, pengalaman, eksperimen, dan kreativitas [22]. Selain inovasi yang sesuai dengan Revolusi 4.0, guru perlu menumbuhkan minat siswa untuk belajar, maka guru dituntut lebih kreatif dalam mengajar [23]. Dibutuhkan guru yang kreatif, dengan menggunakan pembelajaran yang kreatif. Dengan penambahan memakai Google Meet dan Power Point kreativitas dapat ditampilkan dan dipergunakan. 
Hal di atas adalah pembahasan masalah dengan bantuan sumber pustaka. Masalah awalnya adalah adanya hasil nilai ulangan yang kurang memuaskan. Hasil nilai yang kurang memuaskan tersebut akan dibahas dipecahkan dengan pembahasan yang mengacu pada rumusan masalah. Rumusan masalah berbeda dengan masalah. Kalau masalah merupakan kesenjangan antara yang diharapkan dengan yang terjadi, maka rumusan masalah itu merupakan suatu pertanyaan yang akan dicarikan jawabannya melalui pengumpulan data. Namun demikian terdapat kaitan erat antara masalah dan rumusan masalah, karena setiap rumusan masalah penelitian harus didasarkan pada masalah [24]. Rumusan masalah yang akan saya bahas adalah,

1) Bagaimana pembelajaran Sejarah Indonesia sebelum diadakan tindakan?

2) Bagaimana hasil ulangan sebelum diadakan tindakan?

3) Bagaimana penerapan atau penggunaan Google Meet dan Power Point yang dipakai dalam pembelajaran di kelas X AKL 1 Semester Genap tahun pelajaran 2020 -2021?

4) Bagaimana hasil nilai yang didapatkan oleh para siswa dengan tambahan menggunakan sarana pendekatan Google Meet dan Power Point?

5) Bagaimana analisa yang ada dengan hasil nilai ulangan yang kedua tersebut?

6) Bagaimana pendapat siswa dengan penggunaan tambahan Google Meet dan Power Point?

Rumusan masalah tersebut akan dibahas dalam pembahasan. Pembahasan masalah untuk membuktikan bahwa tambahan penggunaan Google Meet dan Power Point bisa untuk meningkatkan hasil nilai ulangan dalam pembelajaran Sejarah Indonesia. Berkaitan dengan hal tersebut tujuan penulisannya adalah untuk meningkatkan hasil nilai ulangan dan lebih memudahkan, lebih membuat semangat para siswa dalam menerima pembelajaran Sejarah Indonesia.

\section{METODE}

Metode penelitian adalah usaha seseorang yang dilakukan secara sistematis mengikuti aturan-aturan guna menjawab permasalahan yang hendak diteliti [25]. Penelitian ini memakai jenis penelitian best practice yang berbasis pada kelas daring (dalam jaringan) atau kelas online yang mengandalkan tersedianya jaringan internet. Bisa juga disebut dengan penelitian tindakan. Penelitian dalam bidang pendidikan bertujuan untuk meningkatkan mutu lingkungan pendidikan, pembelajaran dan cara peserta didik dalam belajar. Hasilnya adalah berupa peningkatan mutu layanan [26]. Mutu layanan yang ada ditunjukan dengan adanya peningkatan nilai. Pembahasannya secara deskripsi dan analisis yang bertujuan untuk meningkatkan hasil pembelajaran berupa nilai hasil ulangan. Pendekatan baru yang digunakan dengan memakai Google Meet dan Power Point dimana pendekatan yang dipakai sebelumnya juga dipakai. Sebelum memakai pendekatan baru, pendekatan dengan menggunakan WhatsApp, dan Google Classroom yang ditambah dengan penggunaan Google Form dan Google Drive untuk menyampaikan bahan-bahan ulangan, juga dengan file materi yang ditulis dalam MsWords yang dikirim dengan Google Classroom.

Penelitian berupa penelitian best practice ini dilakasanakan untuk mata pelajaran Sejarah Indonesia di SMK Negeri 1 Bawang Banjarnegara semester genap tahun 2020 - 2021. Dengan subjek penelitian adalah para siswa kelas $\mathrm{X}$ AKL 1. Jumlah siswa kelas tersebut adalah 36 siswa, yang terdiri atas 4 laki-laki dan 32 perempuan.

Data yang utama berasal dari hasil ulangan sebelum dan sesudah tindakan. Data ulangan sebelum tindakan dianalisa nilai rata-ratanya, nilai tertinggi dan terendah, prosentasenya kemudian dibandingkan dengan hasil ulangan setelah tindakan. Selain data ulangan tersebut, tanggapan uraian para siswa terhadap penggunaan Google Meet dan Power Point juga dijadikan data tambahan dalam penulisan ini.

\section{HASIL DAN PEMBAHASAN}

1) Bagaimana pembelajaran Sejarah Indonesia sebelum diadakan tindakan?

Pembalajaran Sejarah Indonesia di kelas X AKL 1 Semester Genap tahun 2020 - 2021 memakai model daring (dalam jaringan) atau model online atau Pembelajaran Jarak Jauh (PJJ). Dalam PJJ penulis menggunakan sarana WhatsApp, Google Classroom, Google Form, Google Drive, File MsWord berupa materi pelajaran.

Setelah materi pembelajaran ditulis dalam file MsWord, kemudian dikirim melalui Google Classroom. Siswa yang sudah membuka Google Classroom bisa langsung membaca dan mempelajari materi dari sana, kemudian menuliskan kehadiran di Google Classroom tersebut. Materi pelajaran kemudian dipelajari oleh siswa. Dalam satu minggu berikutnya diadakan ulangan berkaitan dengan materi yang sudah diberikan

WhatsApp dipergunakan untuk memberitahu kalau ada ulangan, untuk mengingatkan kalau masih ada siswa yang belum ulangan. Google Classroom untuk mengirimkan materi pelajaran, maupun materi ulangan. Google Form adalah untuk menuliskan soal ulangan berupa soal pilihan ganda. Soal yang yang sudah ditulis dalam MsWords kemudian dipindahkan ke dalam Google Form yang kemudian dikirim kepada siswa melalui Google Classroom. Soal yang sudah dikirim akan tersimpan di dalam Google Drive. Google Drive dipergunakan oleh penulis untuk menyimpan materi, soal ulangan, dan juga jawaban hasil ulangan. Soal ulangan bisa dibuka di Google Drive dan langsung dikerjakan disana, dengan membuka Google Classroom. Setelah selesai mengerjakan para siswa langsung bisa melihat hasinya. 
2) Bagiamana hasil ulangan sebelum diadakan tindakan?

Para siswa sudah mendapatkan materi pelajaran. Kemudian diadakan ulangan satu minggu setelahnya. Soal ulangan dapat dilihat dalam Google Drive melalui Google Classroom. Para siswa setelah ulangan dapat langsung melihat hasilnya. Hasil ulangan seperti yang tertera dalam tabel di bawah ini.

Tabel 1: Hasil Nilai Ulangan Sebelum Tindakan

Hasil Ulangan Sebelum Tindakan

\begin{tabular}{cccc} 
Rentang Nilai & Kriteria & Jumlah Siswa & Persen (\%) \\
\cline { 3 - 4 } & & 14 & 38,89 \\
\hline Antara 61 - 70 & Kurang & 6 & 16,67 \\
\hline Antara 71 - 80 & Cukup & 11 & 30,56 \\
\hline Antara 81 - 90 & Baik & 5 & 13,89 \\
\hline Antara 91 - 100 & Amat Baik Sekali & -- & 0,00 \\
\hline JUMLAH & & $\mathbf{3 6}$ & $\mathbf{1 0 0}$
\end{tabular}

Hasil nilai ulangan dapat dijelaskan dengan melihat tabel tersebut Siswa yang mendapat nilai 60 atau di bawahnya dengan kriteria Kurang ada 38,89\% atau 14 siswa. Siswa yang mendapat nilai antara 61 sampai 70 dengan kriteria Cukup ada 16,67\% atau 6 siswa. Siswa yang mendapat nilai antara 71 sampai 80 dengan kriteria Baik ada $30,56 \%$ atau 11 siswa. Siswa yang mendapat nilai antara 81 sampai 90 dengan kriteria Baik Sekali ada 13,89\% atau 5 siswa. Siswa yang mendapat nilai antara 91 sampai 100 dengan kriteria amat Baik Sekali tidak ada. Penulis menerapkan KKM 70. Ada 20 siswa yang mendapat nilai di bawah KKM, sedangkan yang di atas KKM hanya 16 siswa.

Tabel 2: KKM, Siswa, Nilai Tertinggi, Nilai Terendah, Jumlah Nilai, Rata-Rata Ulangan Sebelum Tindakan

\begin{tabular}{lc} 
Jumlah Siswa & 36 \\
\hline KKM & 70 \\
\hline Nilai Tertinggi & 90 \\
\hline Nilai Terendah & 35 \\
\hline Jumlah Nilai & 2380 \\
\hline Rata-Rata Kelas & 75
\end{tabular}

Setelah melihat kondisi hasil nilai yang diperoleh para siswa, kondisi tersebut perlu diperbaiki. Penulis kemudian menambahan sarana pendekatan pembelajaran dengan Google Meet dan Power Point.

3) Bagaimana penerapan atau penggunaan Google Meet dan Power Point yang dipakai dalam pembelajaran di kelas X AKL 1 Semester Genap tahun pelajaran 2020 -2021?

Siswa diberitahu melalui WhatsApp satu minggu setelah ulangan. Isi pemberitahuan adalah ada materi baru dalam file MsWord dan media Power Point yang dikirim melalui Google Classroom. Materi baru tersebut agar dipelajari. Diberitahukan juga akan ada pertemuan virtual melalui Google Meet pada hari Senin, jam 9.30 waktu pelajaran Sejarah Indonesia. Link akan diberikan dan dibuka pada Senin, jam 9.30. 
Pada waktu pertemuan virtual dengan Google Meet pada hari Senin, jam 9.30 link untuk pertemuan daring dengan Google Meet dibuka. Proses pertemuan virtual dengan siswa dilalui dengan alur sebagai berikut:

a. Link Google Meet diberikan

b. Link Google Meet dibuka

c. Guru membuka atau menerima siswa yang mengikuti pertemuan daring

d. Guru menyapa siswa yang mengikuti pertemuan, dengan menyebut nama, menyambut selamat mengikuti pertemuan daring, semoga sehat.

e. Setelah berlangsung 10 menit untuk sapaan dan menunggu siswa yang hadir dirasakan sudah cukup, kemudian guru menjelaskan materi pelajaran.

f. Penjelasan materi pelajaran dengan menggunakan Power Point yang sudah dibagi kepada para siswa.

g. Setelah selesai menjelaskan, siswa diberi kesempatan untuk bertanya.

$h$. Pembahasan dirasa cukup, guru menutup pembelajaran dengan kalimat penutup dan meminta para siswa untuk keluar dari Google Meet.

i. Menutup Google Meet.

4) Bagaimana hasil nilai yang didapatkan oleh siswa dengan tambahan menggunakan sarana pendekatan Google Meet dan Power Point?

Setelah pertemuan virtual dengan Google Meet dan para siswa diberikan Power Point yang juga digunakan sebagai sarana pembelajaran, satu minggu setelahnya diadakan ulangan yang kedua. Dari ulangan yang kedua diperolehan hasil nilai ulangan yang tertera di tabel bawah ini.

Tabel 3: Hasil Nilai Ulangan Kedua Setelah Tindakan

\begin{tabular}{cccc}
\multirow{2}{*}{ Rentang Nilai } & Kriteria & \multicolumn{2}{c}{ Hasil Ulangan Setelah Tindakan } \\
\cline { 3 - 4 } & & Jumlah Siswa & Persen (\%) \\
\hline Antara 61 - 70 & Kurang & 4 & 11,11 \\
\hline Antara 71 - 80 & Cukup & 7 & 22,22 \\
\hline Antara 81 - 90 & Baik & 7 & 19,44 \\
\hline Antara 91 - 100 & Amat Baik Sekali & 10 & 27,78 \\
\hline JUMLAH & & $\mathbf{3 6}$ & $\mathbf{1 0 0}$
\end{tabular}

Perolehan hasil nilai ulangan kedua setelah tindakan dapat dijelaskan sebagai berikut. Ada empat (4) siswa atau $11,11 \%$ yang mendapat nilai dengan kriteria Kurang atau nilai di bawah atau sama dengan 60 . Nilai antara 61 sampai 70 dengan kriteria Cukup ada delapan (8) siswa atau 22,22\%. Nilai antara 71 sampai 80 dengan kriteria Baik ada tujuh (7) siswa atau 19,14\%. Nilai antara 81 sampai 90 dengan kriteria Baik Sekali ada tujuh (7) siswa atau 19,14 $\%$. Dan nilai antara 91 sampai 100 dengan kriteria Amat Baik Sekali ada sepuluh (10) siswa atau 27,78\%.

Tabel 4: KKM, Jumlah Siswa, Nilai Tertinggi, Nilai Terendah, Jumlah Nilai, Rata-Rata Kelas Tindakan Kedua

KKM 70

\begin{tabular}{lc}
\hline Jumlah Siswa & 36 \\
\hline Nilai Tertinggi & 100 \\
\hline Nilai Terendah & 25 \\
\hline Jumlah Nilai & 2890
\end{tabular}


Rata-Rata Kelas
80,28

5) Bagaimana analisa yang ada dengan hasil nilai ulangan yang kedua tersebut?

Analisa ini adalah dengan membandingkan hasil nilai ulangan yang pertama dan kedua (setelah tindakan). Hasil ulangan pertama dan kedua ada ditabel hasil nilai di bawah ini.

Tabel 5: Hasil Nilai Ulangan Pertama Sebelum Tindakan dan Ulangan Kedua Setelah Tindakan

\begin{tabular}{|c|c|c|c|c|c|}
\hline \multirow{2}{*}{ Rentang Nilai } & \multirow{2}{*}{ Kriteria } & \multicolumn{2}{|c|}{$\begin{array}{c}\text { Hasil Ulangan Sebelum } \\
\text { Tindakan }\end{array}$} & \multicolumn{2}{|c|}{$\begin{array}{c}\text { Hasil Ulangan Setelah } \\
\text { Tindakan }\end{array}$} \\
\hline & & $\begin{array}{c}\text { Jumlah } \\
\text { Siswa }\end{array}$ & Persen & $\begin{array}{c}\text { Jumlah } \\
\text { Siswa }\end{array}$ & Persen \\
\hline$\leq 60$ & Kurang & 14 & 38,89 & 4 & 11,11 \\
\hline Antara $61-70$ & Cukup & 6 & 16,67 & 8 & 22,22 \\
\hline Antara $71-80$ & Baik & 11 & 30,56 & 7 & 19,44 \\
\hline Antara 81 - 90 & Baik Sekali & 5 & 13,89 & 7 & 19,44 \\
\hline Antara 91 - 100 & $\begin{array}{c}\text { Amat Baik } \\
\text { Sekali }\end{array}$ & -- & 0,00 & 10 & 27,78 \\
\hline JUMLAH & & 36 & 100 & 36 & 100 \\
\hline
\end{tabular}

Dari tabel di atas dapat dilihat dan dianalisa bahwa ada peningkatan yang amat jelas. Peningkatan tersebut ada di nilai antara 81 sampai 90 dan antara 91 sampai 100. Yang memperoleh nilai antara 81 sampai dengan 90 dengan kriteria Baik Sekali dari Hasil Nilai Sebelum Tindakan ada 5 siswa atau 13,89\%, setelah diadakan tindakan menjadi 7 siswa atau 19,44\%. Yang memperoleh nilai antara 91 sampai dengan 100 dengan kriteria Amat Baik Sekali dari Hasil Nilai Sebelum Tindakan tidak ada, setelah diadakan tindakan yang mendapatkan nilai tersebut ada 10 siswa atau $27,78 \%$.

Nilai KKM-nya tetap yaitu 70. Yang mendapat nilai di atas KKM sebelum dilakukan tindakan ada 16 siswa, dan setelah ada tindakan ada ada 24 siswa.

Tabel 6: KKM, Jumlah Siswa, Nilai Tertinggi, Nilai Terendah, Jumlah Nilai, Rata-Rata Nilai Sebelum dan Setelah Tindakan

Nilai Ulangan Sebelum Tindakan
Nilai Ulangan Setelah Tindakan

\begin{tabular}{lcc}
\hline KKM & 70 & 70 \\
\hline Jumlah Siswa & 36 & 36 \\
\hline Nilai Tertinggi & 90 & 100 \\
\hline Nilai Terendah & 35 & 25 \\
\hline Jumlah Nilai & 2380 & 2890 \\
\hline Rata-Rata Ulangan Kelas & 75 & 80,28
\end{tabular}


Ulangan dengan KKM 70, baik ulangan sebelum tindakan maupun setelah tindakan. Jumlah siswa 36. Hasil nilai ulangan sebelum tindakan dengan nilai tertinggi 90, setelah diadakan tindakan nilai tertinggi 100. Nilai terendahnya sebelum tindakan adalah 35, namun setelah tindakn 25. Jumlah nilai pada ulangan sebelum tindakan 2380, dan setelah tindakan 2890, dengan selisih 510. Kemudian rata-rata ulangan, pada nilai sebelum tindakan adalah 75 , setelah tindakan 80,28. Selisih rata-rata 5,28. Ada peningkatan 5,28.

6) Bagaimana pendapat siswa dengan penggunaan sarana tambahan Google Meet dan Power Point?

Setelah diadakan tindakan pembelajaran menggunakan Google Meet dan Power Point, dimana aplikasi yang sebelumnya tetap digunakan, satu minggu setelahnya diadakan ulangan. Setelah ulangan para siswa diminta memberikan tanggapan terhadap penggunaan sarana tambahan pembelajaran menggunakan Google Meet dan Power Point. Para siswa diminta untuk menulis tanggapannya dengan cara ditulis tangan, kemudian dikirim melalui WhatsApp ke penulis (guru).

Di bawah ini adalah permintaan penulis kepada para siswa untuk memberikan tanggapan mengenai penggunaan Google Meet dan Power Point melalui WhatsApp.

[12:09, 2/6/2021] Harinto: Selamat siang semangat siang anak2 hebat.

Pada hari Senin tg 25 Januari waktu itu ada Pertemuan Virtual dg Google Meet. Bagi yg mengikuti saya ingin kalian memberikan Tanggapan Pesan / Saran, apakah itu membantu Ulangan yg kedua? Dalam ulangan kedua banyak peningkatan hasil.Silahkan bagi yg mengikuti Pertemuan Virtual pakai Google Meet 25/1 tanngapan kalian saya tunggu lewat japri ke nomor saya. Japri.Tulis di kertas tanggapan anda diberi nama lengkap, nomor, kelas di pojok kanan lalu difoto kirim japri.Mksh

[12:15, 2/6/2021] Harinto: Selamat siang semangat siang anak2 hebat.

Pada hari Senin tg 31 Januari waktu itu saya memberikan Powert Point.

Bagi yg menggunakan, saya ingin kalian memberikan Tanggapan Pesan / Saran, apakah Power Point itu membantu Ulangan yg kedua? Dalam ulangan kedua banyak peningkatan hasil ulangan. Silahkan bagi yg menggunakan Power Point yg saya shaer tg 31/1 tanggapan kalian saya tunggu lewat japri ke nomor saya. Japri. Tulis tanggapan anda, diberi nama lengkap, nomor, kelas di pojok kanan lalu kirim japri ke nomor saya. Mksh

Dengan adanya WhatsApp dari penulis (guru), para siswa kemudian memberikan jawaban dengan ditulis tangan yang kemudian difoto dan dikirim melaui WhatsApp. Mereka menanggapi secara positif. Diantara tanggapan atau jawaban tersebut ada di bawah ini.

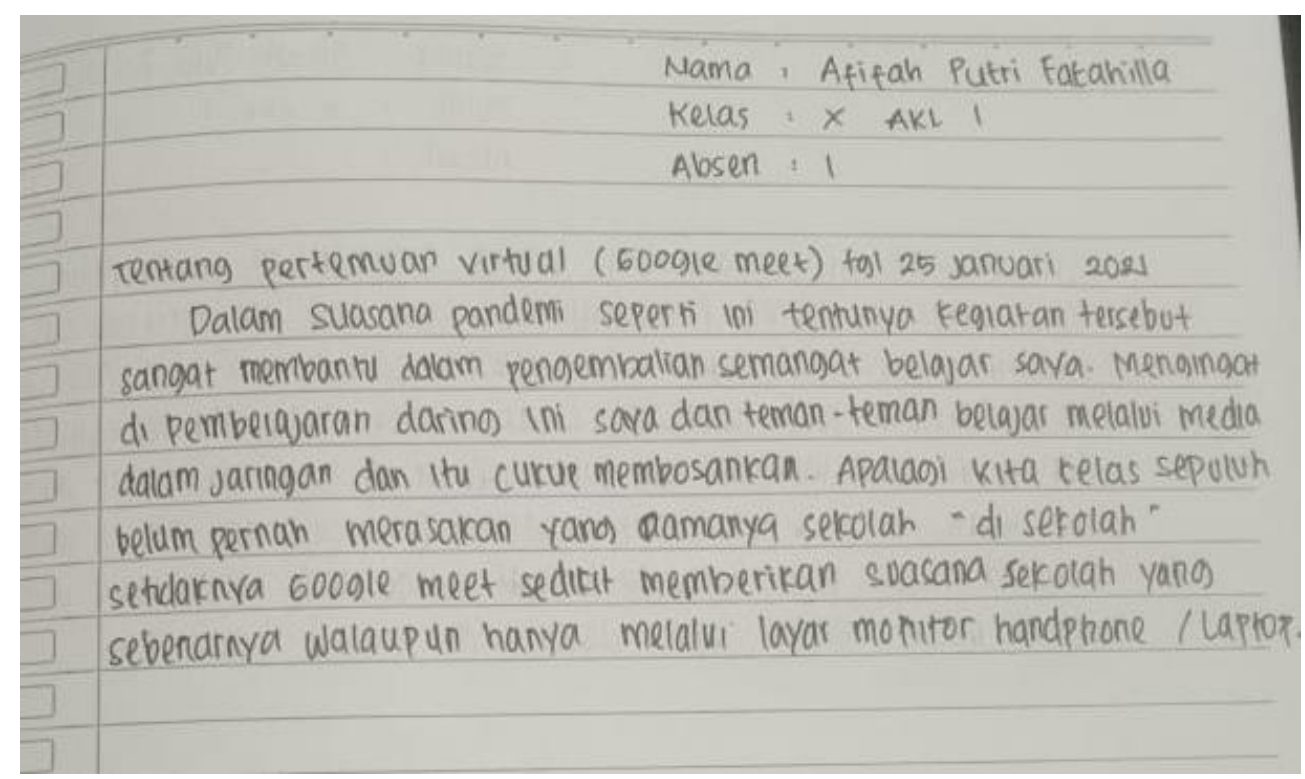

Proceedings homepage: https://conferenceproceedings.ump.ac.id/index.php/pssh/issue/view/4 

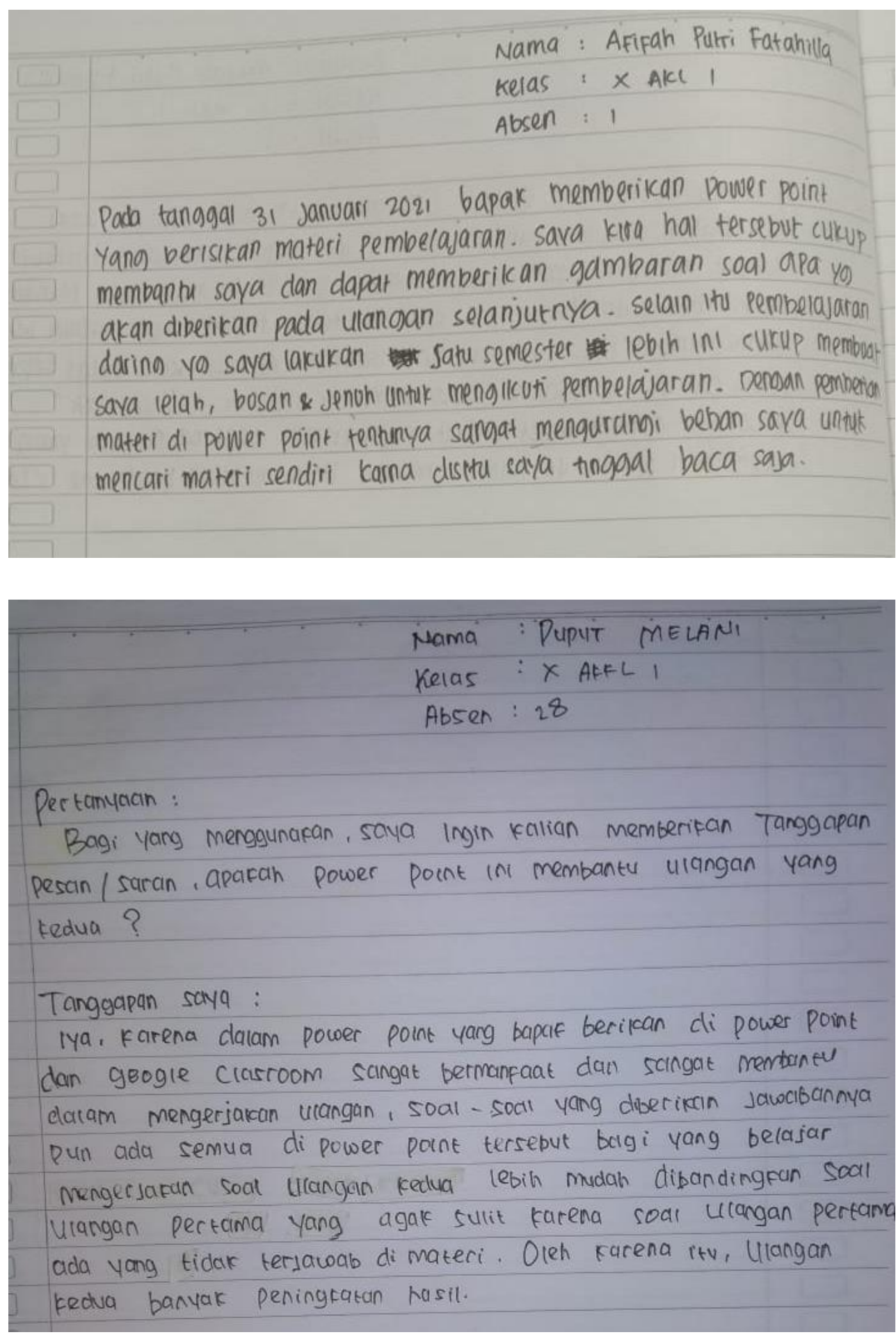

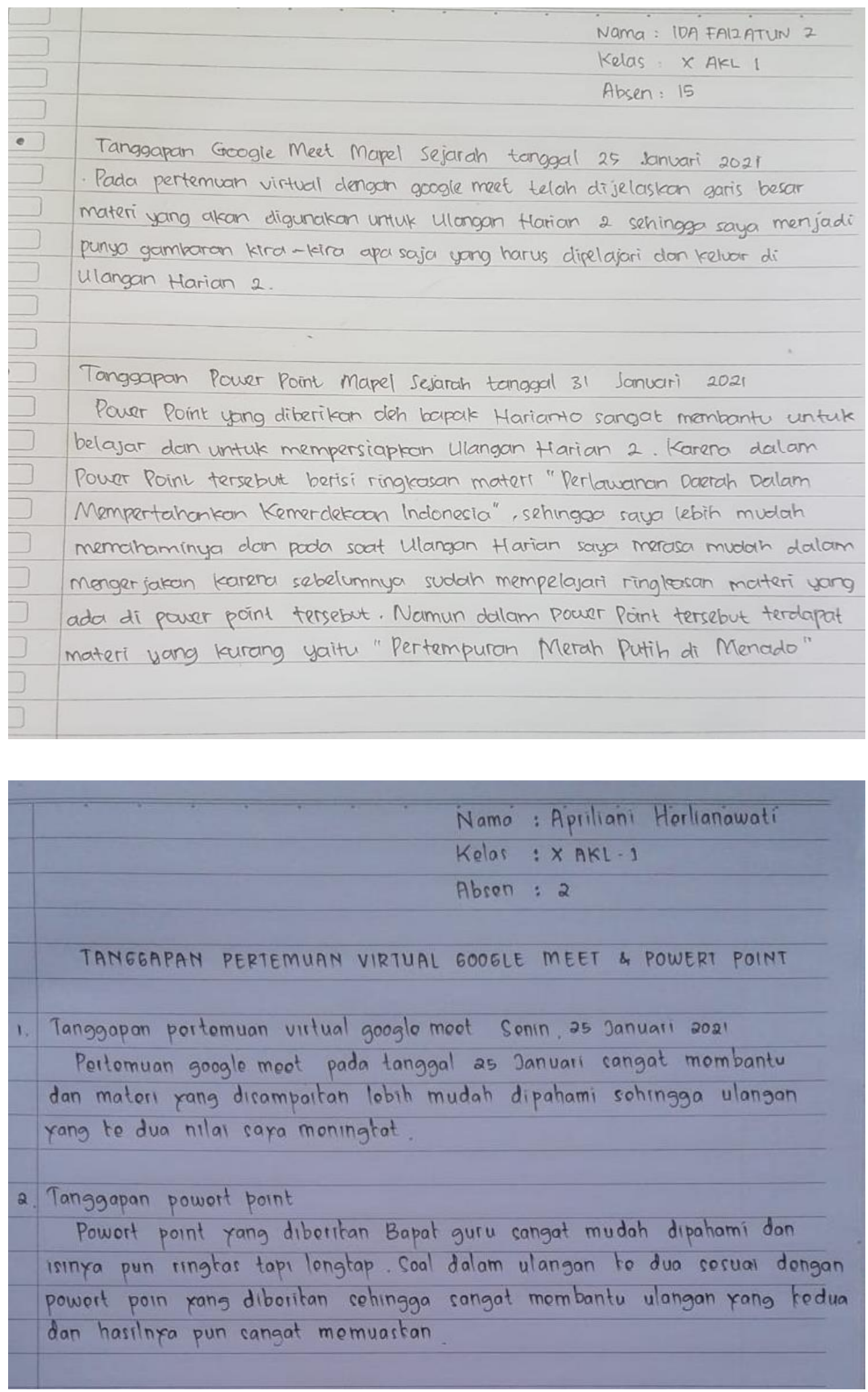


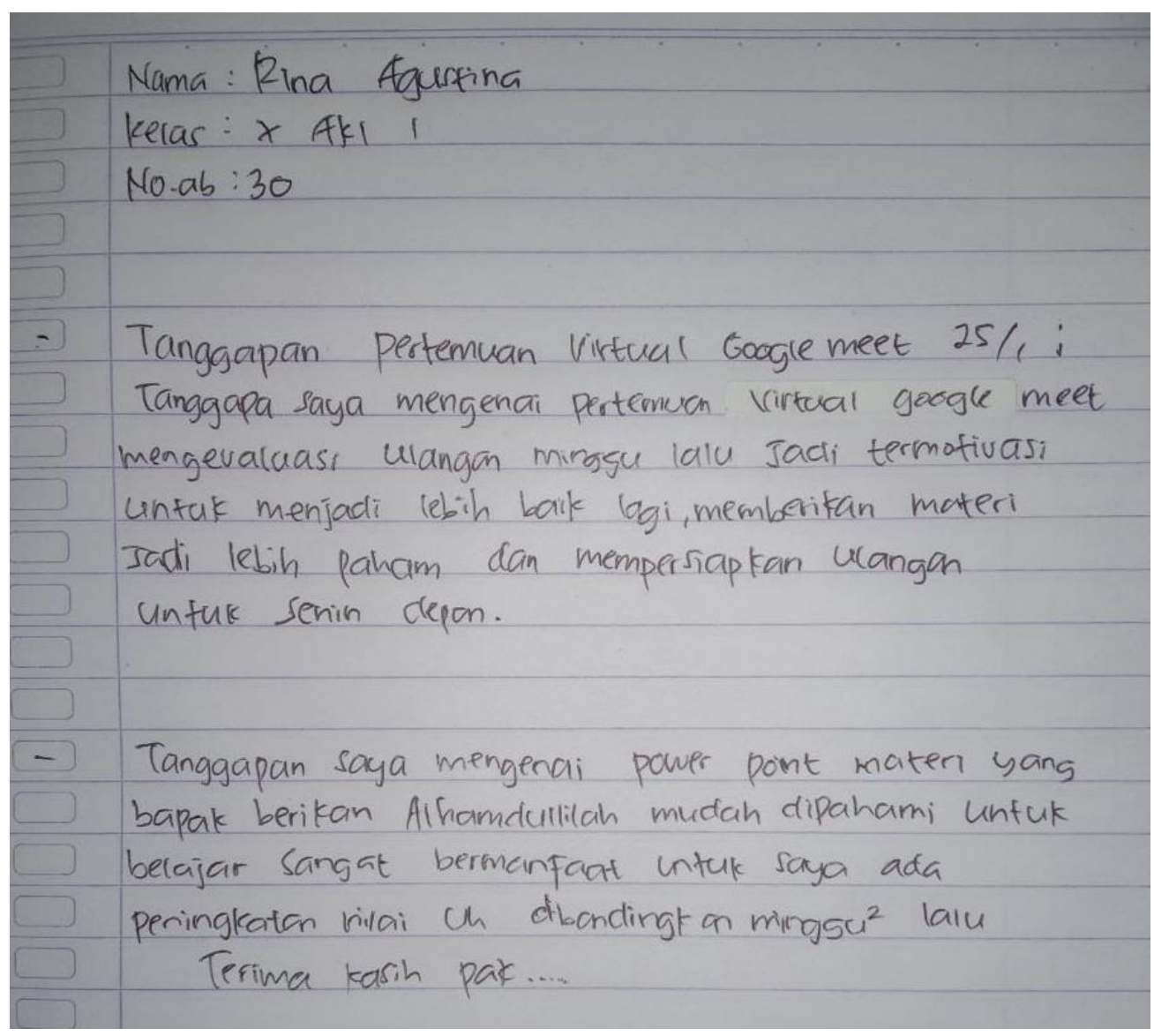

Nama : Yogi
Kelas : $x$ AKL 1
Absen : 36
(1). Tanggapan saya mengenai pertemuan virtual dengan
Google Meet yang dilaksanakan pada 25 januari
cukup membantu dalam ulangan ke 2 karena dijelaskan
materi yang akan digunakan untuk ulangan meskipun
hanya memaparkan garis besarnya saja dan membantu
mengetahui informasi lebih awal sehingga bisa bersiap
untuk melaksanakan ulangan yang ke 2 .
(2.) Tanggapan saya mengenai powerpoint yang disampaikan
pada hari minggu tanggal 31 januari membantu
saya dalam ulangan ke 2 , karena materi yang
disampaikan cukup jelas, to the point, tapi sayangnya
materi pertempuran di menado tidak disampaikan
di powerpoint, sehingga harus mencari sendiri materinya.

\section{KESIMPULAN}

Berdasarkan pelaksanaan tindakan, pembahasan dan analisa di atas maka dapat ditarik suatu kesimpulan sebagai berikut: pertama, ada peningkatan hasil nilai ulangan setelah diadakan tindakan pembelajaran Sejarah 
Indonesia dengan Google Meet dan Power Point. Hal itu merupakan tanda bahwa ada kebenaran dari perkiraan awal, adanya peningkatan hasil nilai ulangan setelah diadakan pembelajaran dengan Google Meet dan Power Point. Kedua, tanggapan para siswa menyatakan bahwa memang dengan Google Meet dan Power Point bermanfaat membantu siswa untuk mendapatkan hasil nilai yang meningkat. Penerapan Google Meet dan Power Point dapat membantu dalam meningkatkan hasil nilai ulangan dalam pembelajaran Sejarah Indonesia dan membuat para siswa lebih semangat dan lebih mudah menerima pembelajaran Sejarah Indonesia.

\section{DAFTAR PUSTAKA}

[1] Kompri. 2016. Motivasi Pembelajaran Perspektif Guru dan Siswa. Bandung: Remaja Rosdakarya. 49 -59.

[2] Ngalimun. 2018. Strategi dan Model Pembelajaran. Yogyakarta: Aswaja Presindo. 29-30.

[3] Suardi, Muh. 2019. Strategi Pembelajaran. Bantul: Parama Ilmu. 124.

[4] Husamah. 2014. Pembelajaran Bauran (Blended Learning). Jakarta: Prestasi Pustakarya. 82-106.

[5] Daryanto dan Syaiful Karim. 2017. Pembelajaran Abad 21. Yogyakarta: Gava Media.

[6] Hayati, Noor. 2020. Pembelajaran di Era Pandemi. Sleman: Deepublish.

[7] Belawati, Tian. 2019. Pembelajaran Online. Banten: Universitas Terbuka. 36.

[8] Fecho, Irwan. 2020. Guratan Pandemi. Tangerang: Pustaka Alvabet.

[9] Belawati, Tian. 2019. Pembelajaran Online. Banten: Universitas Terbuka. 6-8.

[10] Belawati, Tian. 2019. Pembelajaran Online. Banten: Universitas Terbuka. 37-42.

[11] Bilfaqih, Yusuf dan M. Nur Qomarudin. 2015. Esensi Pengembangan Pembelajaran Daring. Yogyakarta: Deepublish, 19-20.

[12] Surat Edaran Nomor 4 tahun 2020 Tentang pelaksanaan Kebijakan pendidikan Dalam Masa Darurat Penyebara Coronavirus Disease (Covid-19). http://pgdikmen.kemdikbud.go.id

[13] Setyorini Punaji. 2020. Desain Pembelajaran. Jakarta: Bumi Aksara. 17.

[14] Setyorini Punaji. 2020. Desain Pembelajaran. Jakarta: Bumi Aksara

[15] W.J.S. Poerwadarminta, W.J.S. 2007. Kamus Umum Bahasa Indonesia. Jakarta: Balai Pustaka. 275.

[16] Suryani, Nunuk. dkk. 2018. Media Pembelajaran Inovatif dan Pengembangannya. Bandung: Remaja Rosdakarya. 2-3.

[17] Belawati, Tian. 2019. Pembelajaran Online. Banten: Universitas Terbuka

[18] Kementeriaan Pendidikan dan Kebudayaan Republik Indonesia. 2015. Sejarah Indonesia Untuk SMA/MA/SMK/ MAK Kelas XII. Jakarta: Kementerian Pendidkan, dan Kebudayaan. Juga ada dalam Moedjanto, G. 1988. Indonesia Abad ke-20: II. Yogyakarta: Kanisius. Dan juga dari buku Ratna Hapsari dan M. Adil. 2017. Sejarah Indonesia untuk SMK/ MAK Kelas X Kurikulum 2013 dengan KI dan KD 2017. Jakarta: Erlangga.

[19] Kamal, Iryad., dkk. 2020. Pembelajaran di Era 4.0. Bandung: Yrama Widya. 24.

[20] Kamal, Iryad., dkk. 2020. Pembelajaran di Era 4.0. Bandung: Yrama Widya. 129.

[21] Arsyad, Azhar. 2019. Media Pembelajaran. Depok: Rajawali Pers. 164.

[22] Muis Joenaidy., Muis. 2019. Konsep dan Strategi Pembelajaran Di Era Revolusi Industri 4.0. Yogyakarta: Laksana. 12-23.

[23] B. Uno, Hamzah, dan Nurdin Mohamad. 2015. Belajar dengan Pendekatan PAILKEM. Jakarta: Bumi Aksara. 151.

[24] Sugiyono. 2017. Metode Penelitian Pendidikan: Pendekatan Kuantitatif, Kualitatif, dan R\&K. Bandung: Alfabeta. 55.

[25] Sukardi. 2016. Metodologi Penelitian Pendidikan: Kompetensi dan Praktiknya. Jakarta: Bumi Aksara, 19.

[26] Suryadi, Asip, dan Ika Berdiati. 2018. Menggagas Penelitian Tindakan Kelas Bagi Guru. Bandung: Remaja Rosdakarya. 13. 